IZA DP No. 9733

To Be Born Is Not Enough:

The Key Role of Innovative Startups

Alessandra Colombelli

Jackie Krafft

Marco Vivarelli

February 2016 


\title{
To Be Born Is Not Enough: The Key Role of Innovative Startups
}

\author{
Alessandra Colombelli \\ Politecnico di Torino and BRICK, Collegio Carlo Alberto \\ Jackie Krafft \\ University of Nice Sophia Antipolis, CNRS-GREDEG
}

Marco Vivarelli

Università Cattolica del Sacro Cuore and IZA

Discussion Paper No. 9733

February 2016

\author{
IZA \\ P.O. Box 7240 \\ 53072 Bonn \\ Germany \\ Phone: +49-228-3894-0 \\ Fax: +49-228-3894-180 \\ E-mail: iza@iza.org
}

\begin{abstract}
Any opinions expressed here are those of the author(s) and not those of IZA. Research published in this series may include views on policy, but the institute itself takes no institutional policy positions. The IZA research network is committed to the IZA Guiding Principles of Research Integrity.

The Institute for the Study of Labor (IZA) in Bonn is a local and virtual international research center and a place of communication between science, politics and business. IZA is an independent nonprofit organization supported by Deutsche Post Foundation. The center is associated with the University of Bonn and offers a stimulating research environment through its international network, workshops and conferences, data service, project support, research visits and doctoral program. IZA engages in (i) original and internationally competitive research in all fields of labor economics, (ii) development of policy concepts, and (iii) dissemination of research results and concepts to the interested public.
\end{abstract}

IZA Discussion Papers often represent preliminary work and are circulated to encourage discussion. Citation of such a paper should account for its provisional character. A revised version may be available directly from the author. 
IZA Discussion Paper No. 9733

February 2016

\section{ABSTRACT \\ To Be Born Is Not Enough: The Key Role of Innovative Startups}

This paper investigates the reasons why entry per se is not necessarily good and the evidence showing that innovative startups survive longer than their non-innovative counterparts. In this framework, our own empirical analysis shows that greater survival is achieved when startups engage successfully in both product innovation and process innovation, with a key role of the latter. Moreover, this study goes beyond a purely microeconomic perspective and discusses the key role of the environment within which innovative entries occur. What is shown and discussed in this contribution strongly supports the proposal that the creation and survival of innovative start-ups should become one qualifying point of the economic policy agenda.

JEL Classification: L26, O33

Keywords: innovation, startups, survival, product innovation, process innovation

Corresponding author:

Marco Vivarelli

Istituto di Politica Economica

Università Cattolica del Sacro Cuore

Largo Gemelli 1

I-20123 Milano

Italy

E-mail: marco.vivarelli@unicatt.it

* This work is supported by a public grant overseen by the French National Research Agency (ANR) as part of the "Investissements d'avenir" program (reference: ANR-10-EQPX-17 - Centre d'accès sécurisé aux données - CASD). 


\section{To be born is not enough: The key role of innovative startups}

\section{INTRODUCTION}

There is a common wisdom - both among scholars and policy makers - that considers the formation of new firms as a positive phenomenon, per se. In this paper, we contend that this view is fruitful and we explore an alternative interpretation that moves from considering startups as extremely heterogeneous and often doomed to early failure.

Distinguishing progressive entry from churning, leadership from defensive selfemployment, innovators from replicators (Section 2), is preliminary to single out innovative entry as the specific driver of increasing competitiveness, job creation and ultimately economic growth (Section 3).

While previous literature identifies innovation as a source of a survival premium and as a predictor of an above-average post-entry performance, the empirical analysis put forward in this paper (Section 4) goes a step further. In particular, it is shown that process innovation - rather than sole risky product innovation - may assure higher chances of survival for young companies.

Once discussed how innovative startups are the key actors of entrepreneurship, attention is moved to the institutional and economic settings that may facilitate the formation of innovative new companies. In particular, in Section 5, the role of knowledge spillovers, human capital, academic spinoffs and venture capitalism is investigated in detail. On the one hand, from a theoretical point of view, the great heterogeneity of firms can be better understood as the explicative framework combines within-firm dimensions and more 
contextual characteristics. On the other hand, from an empirical point of view, the major aim should be to provide a consistent set of evidences on how micro aspects interact with more aggregate features in generating employment and growth when focusing on the key role of innovative start-ups.

Finally, Section 6 concludes and puts forward some general policy implications.

\section{ENTRY IS NOT ENOUGH}

As mentioned in the Introduction, to be a newborn firm is often not enough to be considered as a potential driver of growth and job creation.

On the one hand, according to Schumpeter (1934 and 1939), new firms are the driving force of change and, more generally, an engine for economic development (Audretsch, Keilbach and Lehmann 2006; Koellinger and Thurik 2012; for a comprehensive survey, see Van Praag and Versloot 2007). Indeed, as detailed by Wennekers and Thurik (1999) and Dejardin (2011), startups may play a crucial role in fostering competition, inducing innovation and supporting the emergence of brand-new sectors. Ultimately, newborn firms may substantially contribute to job creation provided that the net effect of new entrants taking over the market shares of incumbents and exiting firms - brings about overall market growth (Malchow-Møller, Schjerning, and Sørensen 2011).

The economic rationale in support of the entrepreneurial role of firm entry is that new entrants should displace obsolescent and less efficient firms in a process of "creative destruction' (see Schumpeter, 1939 and 1943; for an account in an endogenous growth framework, see Aghion and Howitt 1992), which may be singled out as an important micro foundation of productivity dynamics and overall economic growth. From such a 
perspective, the founders of new firms are seen as those individuals Schumpeter labeled as "energetic types" who display their "essential features" by introducing the "new" into various activities and by "breaking with the established routines" usually adhered to by managers (see Santarelli 2006, p. xii).

On the other hand, Schumpeter himself (1934) recognized a key role to the "leader" (that is the initial entrepreneur able to introduce a new product, a new process or a revolutionary organizational change) and an important but ancillary role to the "cluster of imitators" following the leader. While the cluster of followers plays a fundamental role in fostering an upswing and further diffusion of innovation (see Freman, Clark and Soete, 1982 and Freeman and Soete, 1987), it is also populated by passive replicators and would-be entrepreneurs who later reveal to be scarcely innovative and are often doomed to early failure. According to Baumol (2005), these 'replicative' entrepreneurs are those who start a firm very similar to already-existing businesses. Indeed, when considering gross entry across all economic sectors, we encounter a huge multitude of replicators (followers) and very few innovative entrepreneurs (leaders). The point is that the followers - although they often pretend to be innovative - are often not innovative at all. This is explicitly discussed by Baumol (2010), who states that “...in reality, the vast majority of all entrepreneurs appear to be of the replicative variety" (ibidem, p.18). Moreover, even focusing on the genuine innovative entrepreneurs, radical innovators are extremely rare: "Casual empiricism indicates that the bulk of the novelties such entrepreneurs introduce are only slightly better "mousetraps' " (ibidem, p. 50). In contrast with the common wisdom which tends to equalize entrepreneurship with innovation, Baumol correctly clarified that innovative entrepreneurs are more the exceptions, rather than the majority (the so-called 'superstars', see Baumol, Schilling, and Wolff 2009; see also De Jong and Marsili 2015). 
Finally, again on the basis of the seminal contribution by Baumol (1990), we are aware that "Schumpeterian" innovative entrepreneurs (the leaders) coexist not only with their replicators (the followers), but also with purely "defensive and necessity entrepreneurs" (see also Block et al. 2015). The latter being those who enter a new business not because of market opportunities and innovative ideas but merely because they need income to survive (think, for instance to those "escapers from unemployment" who try an entrepreneurial adventure as a consequence of a job loss or induced by the fear to lose their jobs; see Oxenfeldt 1943; Evans and Leighton 1990; Storey 1991 and 1994; Foti and Vivarelli 1994; Vivarelli 2007 and 2013).

In this context, it is not surprising that the empirical evidence concerning industrial dynamics is inconsistent with a view centered on the progressive potentialities of business start-ups.

First of all, the survival rates of newborn firms are impressively low: the available empirical evidence shows that more than 50 percent of startups exit the market within the first five years of activity (Dunne, Roberts, and Samuelson 1989; Reid 1991; Geroski 1995; Mata, Portugal, and Guimaraes 1995; Audretsch and Mahmood 1995; Audretsch, Santarelli, and Vivarelli 1999; Johnson 2005). In more detail, Bartelsman, Scarpetta, and Schivardi (2005), using data for ten OECD countries, found out that about $20-40 \%$ of entering firms fail within the first two years of life, while only 40 to $50 \%$ survive beyond the seventh year (see also OECD 2003, p. 145).

Secondly, entry and exit rates are significantly correlated at the industry level (this "revolving door" evidence is often called "turbulence" by the relevant literature; see Beesley and Hamilton 1984, as the first who introduced the concept). This is one of the uncontroversial "stylized facts" of the entry process pointed out by the seminal survey of 
Paul Geroski (1995, p. 424), who underlined that the "mechanism of displacement, which seems to be the most palpable consequence of entry, affects young, new firms more severely" (see also Baldwin and Gorecki 1987, 1991; Rocha et al. 2015). Indeed - in comprehensive statistical analyses - entry and exit rates were found to be positively and significantly correlated across industries both in OECD countries (Bartelsman, Scarpetta, and Schivardi 2005) and in DCs (Bartelsman, Haltiwanger, and Scarpetta 2004).

On the whole, entry and exit rates are positively and significantly correlated and market 'churning', characterized by a large contingent of revolving door firms, emerges as a common feature of industrial dynamics across different sectors and different countries (for a comprehensive survey, also covering the developing countries, see Quatraro and Vivarelli 2015). This uncontroversial empirical evidence supports a view where entry as such is likely to feed a fringe of marginal, fragile and short-living firms and casts severe doubts on the alternative view that put forwards the alleged role of entry as a vehicle for technological upgrading, productivity growth and employment generation.

\section{THE ROLE OF INNOVATION}

What discussed in the previous section highlight that the entry of new firms is a very complex phenomenon, characterized by a high degree of heterogeneity where a minority of genuine Schumpeterian innovators are neck to neck to innovative followers, passive replicators and defensive and necessity entrepreneurs. Indeed, as in other fields of economics, 'heterogeneity' (see Dosi 1988; Dosi and Nelson 2013) is a key feature in the understanding the nature of startups, explaining the extreme variability in their chances of 
survival, their different post-entry performances and ultimately their diverse potential to affect economic growth (see Santarelli and Vivarelli 2002 and 2007).

However, while gross entry cannot be considered - as such - a solid premise for productivity growth, economic development and ultimately job creation, a completely different picture may emerge when entry is associated with innovation and the focus of the analysis moves from startups to "innovative startups".

First, the foundation of new businesses may be more or less conducive to technological upgrading and productivity growth according to the different sectors in which it occurs. Obviously enough, new technology-based firms (NTBFs; see Acs and Audretsch 1990; Audretsch 1995; Colombo, Delmastro, and Grilli 2004; Colombo and Grilli, 2010) in hightech manufacturing and ICT services play a different role than startups in low-tech manufacturing and traditional services.

More in general, if the main motivation to start a new firm is linked to innovative projects, then higher survival rates and better post-entry performance should be expected. For instance, Arrighetti and Vivarelli (1999), using detailed information from a questionnaire applied to a sample of 147 Italian spinoffs, found that innovative drivers (connected both to the innovative motivations of the newborn firm's founder and to his/her previous innovative experience in the mother firm) were significantly correlated with post-entry performance (see also Vivarelli and Audretsch 1998).

Consistently with what discussed so far, Cefis and Marsili (2006) found a clear evidence of an "innovation premium" in survival patterns of newborn firms. In particular, using the Pavitt's (1984) taxonomy, they showed that young firms (defined as less than four years old) in the "science-based" and "specialized supplier" sectors were characterized by significantly higher chances of survival than firms in other sectors. More specifically, in a 
companion study (Cefis and Marsili 2005) the authors showed that being an innovator increased the expected time of survival by 11 percent compared with non-innovator counterparts.

In more general terms, a bunch of recent studies have demonstrated that the propensity for innovation emerges as a firm's growth driver (see Coad and Rao 2008; Altindag, Zehir, and Acar 2011; Colombelli, Krafft, and Quatraro 2014) and specifically as a positive predictor of survival and an above-average post-entry performance in terms of profitability, export performance and job creation (Esteve-Pèrez, Sanchis, and Sanchis 2004; Raspe and Van Oort 2008; Colombelli, Krafft, and Quatraro 2013, Gkypali et al. 2015; Mitra and Jha, 2015).

The next section is devoted to illustrate a further empirical test of the role played by innovation in distinguishing the average startup from the innovative startup and their correspondent different chances of survival. If there is a distinction between leaders and followers, it should be related to their ability in commanding the different steps of innovation and their articulation in a comprehensive strategy. We investigate this issue further on now.

\section{AN EMPIRICAL TEST}

\subsection{Data}

Our dataset combines two sources of data collected from the French Statistical Office (INSEE): the Annual Business Survey (EAE) and the French Community Innovation Survey (CIS 3). The EAE databank, collected by the Service des Etudes et des Statistiques 
Industrielles (SESSI) comprises longitudinal data on a panel of French firms, with 20 employees or more and operating in the manufacturing industry, over the period 19892007. The databank includes information on employment and sector of activity (NACE). From the EAE we selected all young companies included in the database in 2000 . We define young companies those with an age of 5 years or less. We selected the year 2000 for comparison with the CIS 3.

The second database we use in the analysis is the French Community Innovation Survey (CIS 3). This survey was held in 2000 and provides information on the innovation process of firms in France for the period 1998 - 2000. We matched the respondents to the survey with the set of young companies included in the EAE databank. The resulting sample includes 1090 young companies that are observed over the period $2000-2007$.

\subsection{Variables}

Our dependent variable is the survival time of a young company. The survival time is calculated for all the young companies that responded to the CIS 3. As initial point for calculating the survival time we use our focal year (2000), and we measure the survival time in number of years elapsed since 2000. The survival time is censored to the right on the year 2007, last year for which we have information from the EAE databank.

Our key covariates are the Innovator variables: on the basis of the CIS 3, Innovator is a dummy variable that takes value 1 if a young company has introduced either a product innovation or a process innovation in the focal period and 0 otherwise. Moreover, to disentangle the role of the different types of innovation, we also include the following dummy variables: Product Innovator, which takes value 1 if a young company has introduced a product innovation in the focal period and 0 otherwise, Process Innovator, 
which is equal to 1 if the young company has introduced a process innovation in the same period and 0 otherwise, and Prod\&Proc, which is equal to 1 if the young company has introduced both a product innovation and a process innovation in the same period and 0 otherwise.

Besides the effects of the innovation related variables, we also control for the effects of a number of variables that have proved to affect a firm's survival in previous empirical works. In particular, out of the factors influencing the failure likelihood, the existing literature identifies two key elements, i.e. firm size and age. As far as firm size is concerned, the main argument in the literature is related to the Gibrat's law of proportionate effects. New firms entering the market are more likely to survive if they are set up on a large scale of production (Sutton 1997; Mata and Portugal 1994; Geroski 1995; Lotti et al. 2003 and 2009). The relationship between firm age and survival is grounded on Jovanovic (1982) theory of 'noisy selection'. In this framework, firms discover their efficiency level as compared to the general efficiency level of the sector over time, so that those that are relatively efficient are more likely to survive and grow. The probability of survival hence increases with firms' age. Further empirical evidence confirmed the importance of size and age and showed that their impact on firms' survival changes across different sectors, according to the stage of the industry lifecycle and the technological regime (Caves and Porter 1977; Klepper 1996 and 1997; Agarwal and Audretsch 2001; Mueller and Stegmaier 2015). In light of this literature, we include in our model the current size of a firm at the beginning of the period of observation. Firm Size is derived from the EAE databank and is measured by the number of employees in the year 2000. Firm Age is another variable that has been found to affect survival patterns. Age is calculated as the number of years from the entry of a firm in the EAE databank since 2000 and ranges from 
0 to 5 years. Both variables are in logarithm. Since the relationship between survival and both firm size and age can be non-linear (Evans 1987; Hall 1987; Bruderl and Schussler 1990; Colombelli et al. 2013), we also include the squared term of both variables in the econometric estimation. Finally we also include a set of industrial dummies using the available NACE classification.

Table 1 provides a synthesis of the variables that we will use in the empirical analysis while Table 2 presents the descriptive statistics for all the explanatory variables. About half of the young companies in our sample perform either product or process innovation. In particular, $42 \%$ of the companies are product innovators while $30.7 \%$ are process innovators. The share of young companies that have introduced both product and process innovations in the focal period is equal to $23.5 \%$.

Table 3 reports the correlation matrix for the survival time and the explanatory variables. All the innovation related variables are positively correlated with survival, although Process Innovator reveals the highest correlation. As expected, due to our definitions, the correlation matrix also shows a high correlation among all the innovation related variables.

\subsection{Methodology}

In order to evaluate the effects of innovation on survival, we focus on the duration variable: $\mathrm{T}$. If $\mathrm{T}$ indicates the number of years that young companies in our sample have survived up to 2007 , then we can write the cumulative distribution function $\mathrm{F}$ of the duration time $\mathrm{T}$ as follows:

$$
F(t)=P(T \leq t), \quad 0 \leq \mathrm{t} \leq 7
$$


This specification gives the probability that the duration $\mathrm{T}$ is less than or equal to $\mathrm{t}$. In other words, this function represents the probability that a young company exits the population before $t$ years after 2000 .

The survival function is then defined as:

$S(t)=1-F(t)=P(T>t)$

Which represents the probability that a firm survives t years after 2000 .

The analysis is articulated in two steps. First of all, we check the extent to which differences in survival rates in the sampled firms can be explained by their innovation activity, also disentangling the role of product and process innovation. In this perspective, we compute the empirical survival function by using the life-table approach (Kalbfleisch and Prentice 1980) and then we estimate the survival functions for different categories of firms on the basis of their innovative performance. We also perform statistical tests of equality of survival distributions across the different categories of firms, and in particular the log-rank for discrete variables and the Cox test for the continuous ones. We finally estimate a duration model in which the survival time is a function of a vector of key covariates and control variables.

Previous empirical analyses have adopted different empirical strategies to empirically estimate the determinants of differential survival rates. Some contributions are based on the use of estimation models for binary categorical variables. For example, Audretsch (1991) adopts a logit model on survival rates while Helmers and Rogers (2010) implement a probit model on the probability of firm's exit. Other empirical analyses have instead implemented duration models. Audretsch and Mahmood (1995) and Agarwal and 
Audretsch (2001) applied a Cox proportional hazard regression while Cefis and Marsili (2006) and Colombelli et al. (2013) used a parametric approach.

In this paper we will follow this latter approach and use a lognormal distribution, as the test based on Schoenfeld residuals is significant for the innovation-related variables ( $\mathrm{p}$ values in the range 0.0024-0.0484). This result suggests that our data violates the proportional hazard assumption.

The accelerated time model estimated with a survival time distributed as a lognormal is given by:

$\ln (T)=X \beta+\sigma \varepsilon$

Where $\mathrm{T}$ is the survival time, $X$ is the matrix of the explanatory variables, $\beta$ is the vector of the coefficients to be estimated and $\varepsilon$ is the vector of the residuals assumed to be normally distributed. Since all the explanatory variables are calculated in logarithms, the coefficients $\beta$ of the model can be interpreted as the elasticities of the covariates on the expected survival time. The parameters are estimated by maximum likelihood.

\subsection{Univariate and graphical analysis}

In order to test for differences in the survival due to innovation, we compare the survival rates of the groups of innovators, product innovators, and process innovators with respect to the group of non-innovators. Table 4 shows the life-table estimates of survival rates for the different groups. The table shows that for each year the estimated survival rate for young innovative companies is higher than for non-innovative ones and the difference increases over time. At the end of the period the survival rate of non-innovators is $6.3 \%$ 
lower than that of innovators. Moreover, the survival rate is constantly higher for process innovators than for product innovators. At the end of the period the survival rate of process innovators is about $67.2 \%$ while it is equal to $63.1 \%$ for product innovators.

In order to grasp the different patterns for young innovative companies as compared to non-innovative ones, we also plot the Kaplan-Meier curves for all the groups, i.e. Innovators, Product Innovators, Process Innovators and Prod\&Proc with respect to the group of non-innovators. The Kaplan-Meier estimator is a simple frequency nonparametric estimator, and as such it does not make any ex-ante assumption about the distribution of exit times (Kaplan and Meier 1958). The estimator is given by:

$$
\hat{S}(t)=\prod_{t_{i} \leq t}\left(1-\frac{d_{i}}{n_{i}}\right)
$$

Where $n_{i}$ denotes the number of firms in the risk set at $t_{i}$ and $d_{i}$ the number of exits at $t_{i}$. The product is over all observed exit times that are less than or equal to $t$. Figures 1 to 4 show that the survival path of innovators for all the groups diverges from the one of non-innovators. Figure 5 reveals that the premium for process innovators is higher than the one for product innovators.

Finally, we also investigate whether the differences between the survival functions are statistically significant with respect to our innovator and control variables: for the innovation-related variables we use the log-rank test of equality across strata, which is a non-parametric test, while for the continuous variables we use a univariate Cox proportional hazard regression, which is a semi-parametric model. If the test has a p-value of $0.2-0.25$ or less, it is appropriate to include the variable in the survival model. On the 
contrary, if the predictor has a p-value greater than 0.25 it is very unlikely that it will be statistically significant in a model including other predictors.

Table 5 reports the outcomes of the statistical tests. Results confirm that young innovative companies have higher survival rates, although the corresponding test casts some doubts on the role of the sole product innovation. Table 5 also reveals that the inclusion of firm Size in the final model is appropriate while the test for firm Age is not significant. Although we consider this battery of tests informative on the possible weaker role of the age and product variables, to be on the safer side and based on the extant literature we will include all the considered variables in our multivariate analysis.

\subsection{Multivariate analysis}

In this section we perform a multivariate analysis in order to investigate the determinants of firm survival. With this purpose in mind, we estimate a parametric survival model with lognormal distribution, running different specifications of the model. The innovation related variables are first singularly included in different regression models (columns 1-3), subsequently Product Innovator and Process Innovator are jointly included (column 4) and finally the simultaneous presence of product and process innovation is also tested (column 5).

The results of the econometric estimations are reported in Table 6. The coefficients for Size and Age are quite robust across the different specifications. Moreover, the coefficients on the squared Age and Size term suggest the existence of an inverted U-shaped relationship

with firm survival, as indicated in some previous analyses (Audretsch and Mahmood 1994; Wagner 1994). 
As far as our key covariates are concerned, results show that both Process Innovator and Prod\&Proc increase the chance of survival for young innovative companies. In contrast, the coefficients for the Innovator and Product Innovator variables are not significant. It seems that the high risk associated to the introduction of new products fully counterbalances the innovation premium, while cost-reducing process innovation definitely increase the chances of survival, either associated or not to product innovation.

\section{THE CURRENT DEBATE ABOUT INNOVATIVE STARTUPS}

The previous sections should have convinced the reader that only innovative startups (rather than startups in general) should be considered the core of that kind of entrepreneurship which can be conducive of a genuine Schumpeterian destruction leading to competitive pressure, productivity growth and ultimately economic development and employment creation. The idea that firms engage in product innovation in explorative stages and succeed to survive in the exploitation phase as they move into process innovation has been documented in some previous works (Colombelli, Krafft, Quatraro 2013, 2014a, 2014b). Indeed, the results obtained and discussed in the previous section show that to be born is not enough, but to be product innovator (only) is not either: product innovators have to command the generation of process innovation as well. Successful entry is more likely to occur as the newcomer comes in with a product that is new or significantly improved with respect to existing ones, while survival of this newcomer is more directly related to efficient methods of production of this new or significantly improved product. The newcomer has to be successful in developing new product 
characteristics that will be adopted by the customers, and in producing with efficient costs as well. Development and production are thus joint dimensions of survival entry.

Indeed, not surprisingly, the recent literature specifically devoted to the innovative startups is flourishing. Moreover, both in terms of interpretation of the phenomenon and in terms of its policy implications, the current debate goes beyond a microeconomic perspective (see Sections 2 and 3) and discuss the key role of the environment within which innovative entries occur. In this section, we will try to summarize this debate along some key interpretative issues.

1) There is a strand of literature that investigates the determinants of new firm creation and focuses on the key role of the local socio-economic systems for entrepreneurial dynamics. In this domain, particular emphasis is devoted to the importance of local knowledge spillovers for the process of new firm formation. This idea has been articulated and developed in the Knowledge Spillover Theory of Entrepreneurship (KSTE) (Audretsch 1995; Audretsch and Lehmann 2005; Acs et al. 2009; Modrego et al. 2015). According to the KSTE, the sources of knowledge are incumbent organizations, such as firms, universities and research institutions. In particular, empirical works have demonstrated that knowledge spilling over from universities exerts a key role in the creation of innovative start-ups. For instance, Bonaccorsi et al. (2013) found a positive impact of knowledge codified in academic patents and scientific publications and tacit knowledge embodied in university graduates on the creation of knowledge intensive firms in Italian provinces in 2010. A further step in this direction is provided by Ghio et al. (2016). This paper analyses the role of university knowledge in fostering the creation of innovative start-ups and reveals that regional openness favors the exploitation of 
geographically distant university knowledge spillovers for the creation of innovative start-ups.

Other sources of knowledge at the local level are represented by incubators and science parks in relation to incumbents and clusters within local areas (see Krafft 2004; Ter Val and Boschma 2011; Boschma and Fornahl 2011; Colombelli, Krafft, Quatraro 2014b; Crespi et al. 2015; Hanley et al. 2015; Boschma, 2015). On this issue, local established firms often have a role to play in enabling spinoff entrepreneurship while also providing exit options for startups through acquisition (Buenstorf 2015). In this context, Gkypali et al. (2016) analyses the contribution of Science and Technology Parks (STP) into the corresponding Regional Innovation System (RIS) performance in terms of innovative activities by local firms. Results from their empirical analysis show that the contribution of the examined STP to the performance of the Western Greece RIS diminishes along with the decrease in investment levels by local incumbents.

While the bulk of the empirical analyses on the KSTE focuses on the size of the local knowledge, this approach often neglects the heterogeneous nature of knowledge. Indeed, Colombelli (2016) shows that not only the amount of knowledge available at the local level, but also the characteristics of that knowledge in terms of variety and similarity play a key role in shaping the creation of innovative start-ups. In particular, results indicate that the higher the variety in the combination of technologies in a region, the higher is the number of innovative start-ups. However, her empirical analysis also suggests that a key condition for the creation of new innovative start-ups is the availability of local knowledge bases stemming from the combination of similar technologies. 
2) Another stream of literature on innovative startups focuses on academic spin-offs. Many contributions have addressed the issue of managerial and organizational challenges that university spin out companies may face, and the importance of Technology Transfer Offices (TTOs) resources and capabilities to reduce the knowledge gap that new ventures may encounter (Lockett and Wright 2005; Lockett et al. 2005; Croce et al., 2014; Muscio et al., 2015). Partially in contrast with this conventional wisdom, Meoli and Vismara (2016) show that the relationship between the administration of the parent university and the academic spin-offs may be controversial. Indeed, their results confirm that effective administrative support from the parent university leads academics to create more technology-based spin-offs; however, the parent university's administrative inadequacy may lead to a larger number of non-technology-based spin-offs (such as - for instance- consultancy activities). In particular, their empirical evidence reveals a U-shaped relationship between the number of administrative staff within a university and the rate of establishment of non-technology-based spin-offs: when university administrative support is either insufficient or highly bureaucratic, academics react by establishing non-technology-based spin-offs to achieve improved cash and human resource management.

3) There is also a wide body of literature that focuses on the personal and social characteristics of the entrepreneur as key determinants of innovative startups performances. For instance, many studies suggest that entrepreneurs' cognitive characteristics, such as intention and motivation, are good predictors of firm entry and post-entry performance (see Vivarelli 2007 and 2013; BarNir 2012; Cortese et al. 2015; Kolstaad and Wiig 2015). By the same token, entrepreneurs' human and 
social capital are key drivers, as well (Colombo et al. 2004; Colombo and Grilli 2005; BarNir 2012; Szopa 2013; Agarwal and Shah 2014; Cortese et al. 2015; Hafer and Jones 2015; Kaiser and Muller 2015). Moreover, previous studies highlighted the importance of contextual factors, such as family characteristics, network and social support (Söderblom 2015). Also the origin of entrepreneurs, like prior knowledge, past positions and industry experience may affect the development and growth of new firms (Breschi et al. 2014). Finally, empirical evidence reveal a positive link between organizational capital and firm performance (Renko et al. 2009; Cortese et al. 2015).

In this domain, Rojas and Huergo (2016) studies the effects of the characteristics of entrepreneurs on the public financial support for New Technology Based Firms (NTBFs) in Spain. Their results reveal a positive relationship between the probability to participate in the public aid program and entrepreneurs' features like having low experience in management, seeking personal satisfaction, being oriented toward growth and having closer ties to the public system of R\&D.

4) Finally, the literature also deeply explores the issue of how innovative start-ups should be funded. The role of venture capitalists (VCs) is here widely acknowledged (Grilli and Murtinu, 2014 and 2015), especially when start-ups are involved in strategic alliances (Kaplan and Lerner 2014; Lindsey 2008; Hsu 2006). Evidence shows that - because of their distinctive abilities - VCs can shape the formation of the alliance, improve its operation, and increase its reputation and valuation. In this framework, Jolink and Niesten (2016) is one of the first attempts to address the impact of VCs on governance decisions for alliances; according to their results, VCs are not only scouts, financiers and coaches, but they can also play 
a liaison role that has not been previously documented in the literature on innovative start-ups.

\section{CONCLUSIONS AND POLICY IMPLICATIONS}

As clarified by Scott Shane (2009 p. 41): "Policy makers believe a dangerous myth. They think that start-up companies are a magic bullet that will transform depressed economic regions, generate innovation, create jobs. This belief is flawed because the typical start-up is not innovative, creates few jobs, and generates little wealth".

What discussed in this paper should be intended as a suggestion to policy makers to move their attention from simple startups to innovative startups as a key source of sustainable value creation. In our view, the interpretative framework and the evidence provided in this study may represent a basis for further interesting investigations, and especially for the identification of key policy issues. In particular, as documented in previous literature (see Section 2), newborn firms are often doomed to early failure, unless characterized by strong innovative drivers (see Section 3). Indeed, as shown in Section 4, innovative ventures exhibit higher survival rates and this is particularly true when process innovation is taken into account: while product innovations may be risky and expose a newborn firm to early failure, process innovations emerge as a safe competitive driver, able to increase the chances of survival (innovation premium). Therefore, both the research investigation and the policy activities should be focused on the circumstances that facilitate the formation of innovative startups and the survival of young innovative firms (see Pellegrino et al., 2012; 
García-Quevedo et al., 2014; Czarnitzki and Delanote 2015). Some of these features are analyzed in detail in Section5.

Indeed, the creation and survival of innovative start-ups should become one qualifying point of every policy agenda in both the short- and long-term. Policy makers should focus on shaping a fruitful local/regional innovation system including a variety of interrelated agents like firms, universities, science parks, incubators as well as venture funding organizations. Such a regional innovation system should be able to generate knowledge spillovers, academic spinoffs and the formation of highly specialized human and social capital, including agents such as business angels and venture capitalists. All these factors clearly emerge as facilitating drivers of the innovative startups, which are the bulk of that Schumpeterian "creative destruction" able to foster competitiveness and ultimately economic growth and job creation. 


\section{References}

Acs, Z. J., \& Audretsch,. D. B. (1990). Innovation and Small Firms. Cambridge, MA: MIT Press.

Acs, Z.J., Braunerhjelm, P., Audretsch, D.B., \& Carlsson, B. (2009). The knowledge spillover theory of entrepreneurship. Small Business Economics, 32(1), 15-30.

Agarwal, R. \& Audretsch, D.B. (2001). Does Entry Size Matter? The Impact of the Life Cycle and Technology on Firm Survival. Journal of Industrial Economics, 49, 21-43.

Agarwal, R. \& Shah, S.K. (2014). Knowledge sources of entrepreneurship: Firm formation by academic, user and employee innovators. Research Policy, 43, 1109-1133.

Aghion, P. \& Howitt, P. (1992). A Model of Growth Through Creative Destruction, Econometrica, 60, 323-51.

Altindag, E., Zehir, C. \& Acar, A. Z. (2011). Strategic Orientations and their Effects on Firm Performance in Turkish Family Owned Firms. Eurasian Business Review 1 (1) : 1836.

Arrighetti, A., \& Vivarelli, M. (1999). The Role of Innovation in the Postentry Performance of New Small Firms: Evidence from Italy. Southern Economic Journal 65 (4) : 927-39.

Audretsch, D.B. (1991). New-Firm Survival and the Technological Regime. The Review of Economics and Statistics, 73, 441-50.

Audretsch, D. B. (1995). Innovation and Industry Evolution. Cambridge, MA: MIT Press.

Audretsch, D. B., Keilbach, M. C. \& Lehmann, E. E. (2006). Entrepreneurship and Economic Growth. Oxford: Oxford University Press.

Audretsch, D.B. \& Lehmann, E.E. (2005). Does the knowledge spillover theory of entrepreneurship hold for regions? Research Policy, 34, 1191-1202.

Audretsch, D. B., \& Mahmood, T. (1995). New Firm Survival: New Results Using a Hazard Function. Review of Economics and Statistics, 77 (1), 97-103.

Audretsch, D. B., \& Mahmood, T. (1994). Firm Selection and Industry Evolution: The Post-entry Performance of New Firms. Journal of Evolutionary Economics, 4, 243-60.

Audretsch, D. B., Santarelli, E. \& Vivarelli, M. (1999). Start Up Size and Industrial Dynamics: Some Evidence from Italian Manufacturing. International Journal of Industrial Organization, 17 (7), 965-83. 
Baldwin, J. R., \& Gorecki., P. K. (1987). Plant Creation Versus Plant Acquisition: The Entry Process in Canadian Manufacturing. International Journal of Industrial Organization, 5 (1), 27-41.

BarNir, A. (2012). Starting technologically innovative ventures: Reasons, human capital, and gender. Management Decision, 50, 399-419.

Bartelsman E., Haltiwanger, J. \& Scarpetta, S. (2004). Microeconomic Evidence of Creative Destruction in Industrial and Developing Countries. Policy Research Working Paper 3464. World Bank, Policy Research Department, Washington, DC.

Bartelsman, E., Scarpetta, S. \& Schivardi, F. (2005). Comparative Analysis of Firm Demographics and Survival: Evidence from Micro-level Sources in OECD Countries. Industrial and Corporate Change, 14 (3), 365-91.

Baumol, W. J. (1990). Entrepreneurship: Productive, Unproductive and Destructive. Journal of Political Economy, 98 (5), 893-921.

Baumol, W. J. (2005). Entrepreneurship and Invention: Toward Their Microeconomic Value Theory, AEI-Brookings Joint Center for Regulatory Studies, related publication n.05-38, Washington, Joint Center.

Baumol, W. J. (2010). The Microtheory of Innovative Entrepreneurship. Princeton: Princeton University Press.

Baumol, WJ., Schilling M. \& Wolff, E. (2009). The Superstars Inventors and Entrepreneurs: How Were They Educated? Journal of Economic and Management Strategy, 18, 711-28.

Beesley, M. E., \& Hamilton, R. T (1984). Small Firms' Seedbed Role and the Concept of Turbulence. Journal of Industrial Economics, 33 (2), 217-31.

Block, J.H., Kohn, K., Miller, D \& Ullrich, K. (2015). Small Business Economics, 44(1), 37-54.

Bonaccorsi, A., Colombo, M. G., Guerini, M., \& Rossi-Lamastra, C. (2013). University specialization and new firm creation across industries. Small Business Economics, 41(4), 837-863.

Boschma, R. (2015). Do spinoff dynamics or agglomeration externalities drive industry clustering? A reappraisal of Steven Klepper's work, Industrial and Corporate Change, 24(4), 859-73.

Boschma, R., \& Fornahl, D. (2011). Cluster evolution and a roadmap for future research, Regional Studies, 45(10), 1295-1298. 
Breschi, S., Lenzi, C., Malerba, F. \& Mancusi, M.L. (2014). Knowledge-intensive entrepreneurship: sectoral patterns in a sample of European high-tech firms. Technology Analysis and Strategic Management, 26, 751-764.

Bruderl, J. \& Schussler, R. (1990). Organizational Mortality: The Liabilities of Newness and Adolescence. Administrative Science Quarterly, 35, 530-547.

Buenstorf, G. (2015). Schumpeterian incumbents and industry evolution, Journal of Evolutionary Economics, DOI 10.1007/s00191-015-0423-7.

Caves, R. \& Porter, M. (1977). From Entry Barriers to Mobility Barriers. Quarterly Journal of Economics, 91, 241-261.

Cefis, E., \& Marsili, O. (2005). A Matter of Life and Death: Innovation and Firm Survival. Industrial and Corporate Change, 14 (6), 1167-92.

Cefis, E., \& Marsili, O. (2006). Survivor: The Role of Innovation in Firm's Survival. Research Policy, 35(5), 626-41.

Coad, A., \& Rao, R. (2008). Innovation and Firm Growth in High-tech Sectors: A Quantile Regression Approach. Research Policy, 37(4), 633-48.

Colombelli, A. (2016). The impact of local knowledge bases on the creation of innovative start-ups in Italy Small Business Economics, forthcoming.

Colombelli, A., Krafft, J. \& Quatraro, F. (2013). Properties of knowledge base and firm survival: Evidence from a sample of French manufacturing firms. Technological Forecasting and Social Change, 80 (8), 1469-84.

Colombelli, A., Krafft, J. \& Quatraro, F. (2014a). High Growth Firms and Technological Knowledge: Do gazelles follow exploration or exploitation strategies? Industrial and Corporate Change, 23(1), 261-291.

Colombelli, A., Krafft, J. \& Quatraro, F. (2014b). The emergence of new technology-based sectors in European regions : A proximity-based analysis of nanotechnology. Research Policy, 43(10), 1681-1696.

Colombo, M. G., Delmastro, M., \& Grilli, L. (2004). Entrepreneurs' Human Capital and the Start-up Size of New Technology-based Firms. International Journal of Industrial Organization, 22 (8-9), 1183-211.

Colombo, M. G., \& Grilli, L. (2010). On Growth Drivers of High-tech Start-ups: Exploring the Role of Founders'Human Capital and Venture Capital. Journal of Business Venturing, 25 (6), 610-26. 
Cortese, C.G., Ghislieri, C., Molino, M., Mercuri, A., Colombelli, A., Cantamessa, M., Paolucci, E., Carossa, M. \& Carpaneto, A. (2015), Promuovere lo sviluppo delle start-up. Sviluppo e Organizzazione, 265, 69-78.

Crespi, F., Ghisetti, C. \& Quatraro, F. (2015). Environmental and innovation policies for the evolution of green technologies: a survey and a test. Eurasian Business Review, 5(2), 343-370.

Croce, A., Grilli, L. \& Murtinu, S. (2014). Venture capital enters academia: an analysis of university-managed funds. Journal of Technology Transfer, 39(5), 688-715.

Czarnitzki, D \& Delanote, J. (2015). R\&D policies for young SMEs: input and output effects. Small Business Economics, 45(3), 465-85.

Dejardin, M. (2011). Linking Net Entry to Regional Economic Growth. Small Business Economics, 36 (4), 443-60.

De Jong, J.P.J. \&Marsili, O. (2015). The distribution of Schumpeterian and Kirznerian opportunities. Small Business Economics, 44(1), 19-35.

Dosi, G. (1988). Sources, Procedures and Microeconomic Effects of Innovation. Journal of Economic Literature, 26, 1120-71.

Dosi, G., \& Nelson, R. R. (2013). The Evolution of Technologies: An Assessment of the State-of-the-Art. Eurasian Business Review, 3 (1), 3-46.

Dunne, T., Roberts, M. J., \& Samuelson, L. (1989). The Growth and Failure of US Manufacturing Plants. Quarterly Journal of Economics, 104(4), 671-98.

Esteve-Pérez S., Sanchis, A., \& Sanchis, J. A. (2004). The Determinants of Survival of Spanish Manufacturing Firms. Review of Industrial Organization, 25 (3), 251-73.

Evans, D. (1987). Tests of Alternative Theories of Firm Growth. Journal of Political Economy, 95, 657-74.

Evans, D. S., \& Leighton, L. S. (1990). Small Business Formation by Unemployed and Employed Workers. Small Business Economics, 2 (4), 319-30.

Foti, A., \& Vivarelli., M. (1994). An Econometric Test of the Self-employment Model: The case of Italy. Small Business Economics, 6 (2), 81-93.

Freeman, C., Clark, J. \& Soete, L. (1982). Unemployment and Technical Innovation. London: Pinter.

Freeman, C. \& Soete, L. (eds) (1987). Technical Change and Full Employment. Oxford: Basil Blackwell. 
García-Quevedo, J., Pellegrino, G. \& Vivarelli, M. (2014). R\&D Drivers and Age: Are Young Firms Different?. Research Policy, 43, 1544-56.

Geroski, P. A. (1995). What do We know about Entry? International Journal of Industrial Organization, 13 (4), 421-40.

Ghio, N., Guerini, M. \& Rossi-Lamastra, C..(2016). University knowledge and the creation of innovative start-ups: An analysis of the Italian case. Small Business Economics, forthcoming.

Gkypali, A., Kokkinos, V., Boura, C. \& Tsekouras, K. (2016). Revisiting the role of Science \& Technology Parks in the Heart of the Fiscal Austerity Era: The case of a lagging Greek RIS. Small Business Economics, forthcoming.

Gkypali, A., Rafailidis, A. \& Kostas Tsekouras (2015). Innovation and export performance: do young and mature innovative firms differ? Eurasian Business Review, $5(2), 397-415$

Grilli, L. \& Murtinu, S. (2014). Government, venture capital and the growth of European high-tech entrepreneurial firms. Research Policy, 43(9), 1523-43.

Grilli, L. \& Murtinu, S. (2015). New technology-based firms in Europe: market penetration, public venture capital, and timing of investment, Industrial and Corporate Change, 24(5), 1109-48.

Hafer, R.W. \& Jones, G. (2015). Are entrepreneurship and cognitive skills related? Some international evidence. Small Business Economics, 44(2), 283-298.

Hall, B. H. (1987). The relationship between firm size and firm growth in the US manufacturing sector. The Journal of Industrial Economics, 35, 583-606.

Hanley, A., Liu, W.H. \& Vaona, A. (2015). Credit depth, government intervention and innovation in China: evidence from the provincial data. Eurasian Business Review, 5(1), 73-98.

Helmers C., \& Rogers,M. (2010). Innovation and the Survival of New Firms in the UK. Review of Industrial Organization, 36, 227-248.

Hsu, D. H. (2006). Venture capitalists and cooperative start-up commercialization strategy. Management Science, 52(2), 204-219.

Johnson, P. S. (2005). Targeting Firm Births and Economic Regeneration in a Lagging Region. Small Business Economics, 24 (5), 451-64. 
Jolink, A. \& Niesten, E. (2016). The Impact of Venture Capital on Governance Decisions in Collaborations with Start-ups. Small Business Economics, forthcoming this special issue.

Jovanovic, B. (1982). Selection and evolution of industry. Econometrica, 50, 649-670.

Kaiser, U \& Muller B. (2015). Skill heterogeneity in startups and its development over time. Small Business Economics, 45(4), 787-804.

Kalbfleisch, J.D. \& Prentice, R.L. (1980). Statistical Analysis of Failure Time Data, New York: Wiley.

Kaplan, E. L., \& Meier, P. (1958). Non-parametric Estimation from Incomplete Observations. J. Am. Stat. Assoc., 53, 457-481.

Kaplan, S. \& Lerner, J. (2014). Venture capital data: Opportunities and challenges. NBERCRIW conference on measuring entrepreneurial businesses: Current knowledge and challenges, December 2014.

Klepper, S. (1996). Entry, Exit, Growth, and Innovation over the Product Life Cycle. American Economic Review, 86(3), 562-83.

Klepper, S. (1997). Industry Life Cycles. Industrial and Corporate Change, 6, 145-81.

Koellinger, P., \& Thurik, A. R. (2012). Entrepreneurship and the Business Cycle. Review of Economics and Statistics, 94 (4), 1143-56.

Kolstad, I. \&Wiig, A. (2015). Education and entrepreneurial success. Small Business Economics, 44(4), 783-796.

Krafft, J. (2004). Entry, Exit and Knowledge: Evidence from a cluster in the infocommunications. Research Policy, 33(10), 1687-1706.

Lindsey, L. (2008). Blurring firm boundaries: The role of venture capital in strategic alliances. The Journal of Finance, 63(3), 1137-1168.

Lockett, A., \& Wright, M. (2005). Resources, capabilities, risk capital and the creation of university spin-out companies. Research Policy, 34, 1043-1057.

Lockett, A., Siegel, D., Wright, M., \& Ensley, M.D. (2005). The creation of spin-off firms at public research institutions: managerial and policy implications. Research Policy, 34, 981-993.

Lotti, F., Santarelli, E. \& Vivarelli, M. (2003). Does Gibrat's Law Hold Among Young, Small Firms? Journal of Evolutionary Economics, 13, 213-35. 
Lotti, F., Santarelli, E. \& Vivarelli, M. (2009). Defending Gibrat's Law as a Long-Run Regularity. Small Business Economics, 32, 31-44.

Malchow-Møller, N., Schjerning, B. \& Sørensen, A. (2011). Entrepreneurship, Job Creation and Wage Growth. Small Business Economics, 36 (1), 15-32.

Mata, J., \& Portugal, P. (1994). Life duration of new firms. Journal of Industrial Economics, 42, 227-246.

Mata, J., Portugal, P. \& Guimaraes, P. (1995). The Survival of New Plants: Start-up Conditions and Post-entry Evolution. International Journal of Industrial Organization, 13 (4), 459-82.

Meoli, M. \& Vismara, S. (2016), University support and the creation of technology and non-technology academic spin-offs. Small Business Economics, forthcoming.

Mitra, A. \& Jha, A.K. (2015). Innovation and employment: a firm level study of Indian industries. Eurasian Business Review, 5(1), 45-71.

Modrego, F., McCann, P., Foster, W.E. \& Olfert, M.R. (2015). Regional entrepreneurship and innovation in Chile: a knowledge matching approach. Small Business Economics, 44(3), 685-703.

Mueller, S. \& Stegmaier, J. (2015). Economic failure and the role of plant age and size. Small Business Economics, 44(3), 621-638.

Muscio, A., Quaglione, D. \& Vallanti, G. (2015), University regulation and universityindustry interaction: a performance analysis of Italian academic departments, Industrial and Corporate Change, 24(5), 1047-79.

OECD (2003), The Sources of Economic Growth in OECD Countries, Paris.

Oxenfeldt, A. R. (1943). New Firms and Free Enterprise: Pre-War and Post-War Aspects. Washington, DC: American Council on Public Affairs.

Pellegrino, G., Piva, M. \& Vivarelli, M. (2012), Young Firms and Innovation: A Microeconometric Analysis. Structural Change and Economic Dynamics, 23, 329-40.

Quatraro, F. \& Vivarelli, M. (2015). Drivers of Entrepreneurship and Post-entry Performance of Newborn Firms in Developing Countries. World Bank Research Observer, $30,277-305$.

Raspe, O., \& Van Oort, F. G. (2008). Firm Growth and Localized Knowledge Externalities. Journal of Regional Analysis and Policy, 38 (2), 100-16.

Reid, G. C. (1991). Staying in Business. International Journal of Industrial Organization, 9 (4), 545-56. 
Renko, M., Carsrud, A., \& Brännback, M. (2009). The effect of a market orientation, entrepreneurial orientation, and technological capability on innovativeness: A study of young biotechnology ventures in the United States and in Scandinavia. Journal of Small Business Management, 47, 331-369.

Rocha, V., Carneiro, A. \& Varum, C.A. (2015). Entry and exit dynamics of nascent business owners. Small Business Economics, 45(1), 63-84.

Rojas, F. \& Huergo, E. (2016). Characteristics of entrepreneurs and public support for NTBFs. Small Business Economics, forthcoming.

Santarelli, E. (2006). Introduction, in E. Santarelli (ed.), Entrepreneurship, Growth, and Innovation: The Dynamics of Firms and Industries, New York, Springer, xiii-xx.

Santarelli, E., \& Vivarelli, M. (2002). Is Subsidizing Entry an Optimal Policy? Industrial and Corporate Change, 11 (1), 39-52.

Santarelli, E., \& Vivarelli, M. (2007). Entrepreneurship and the Process of Firms' Entry, Survival and Growth. Industrial and Corporate Change, 16 (3), 455-88.

Schumpeter, J. A. (1934). The Theory of Economic Development. Cambridge, MA: Harvard University Press.

Schumpeter, J. A. (1939). Business Cycles: A Theoretical, Historical and Statistical Analysis of the Capitalist Process. New York: McGraw-Hill.

Schumpeter, J. A. (1943). Capitalism, Socialism and Democracy. New York: Harper.

Shane, S. (2009). Why Encouraging More People To Become Entrepreneurs Is Bad Public Policy. Small Business Economics, 33 (2), 141-9.

Söderblom, A., Samuelsson, M., Wiklund, J. \& Sandberg, R. (2015). Inside the black box of outcome additionality: Effects of early-stage government subsidies on resource accumulation and new venture performance. Research Policy, 44, 1501-1512.

Storey, D. J. (1991). The Birth of New Firms - Does Unemployment Matter? A Review of the Evidence. Small Business Economics, 3 (3), 167-78.

Storey, D. J. (1994). Understanding the Small Business Sector. London: Routledge.

Sutton, J. (1997). Gibrat's legacy. Journal of Economic Literature, 35, 40-59.

Szopa, A. (2013). Intellectual capital and business performance in university spin-off companies. In Ordóñez de Pablos, P.a, Tennyson, R.b, Zhao, J. (eds) Intellectual Capital Strategy Management for Knowledge-Based Organizations, Hershey: PA, Business Science Reference, pp. 215-224. 
Ter Val, A., \& Boschma, R. (2011). Co-evolution of firms, industries and networks in space. Regional Studies, 45(7), 919-933.

van Praag, M. C., \& Versloot, P. H. (2007). What Is the Value of Entrepreneurship?, A Review of Recent Research. Small Business Economics, 29 (4), 351-82.

Vivarelli, M. (2007). Entry and Post-Entry Performance of Newborn Firms. London: Routledge.

Vivarelli, M. (2013). Is Entrepreneurship Necessarily Good? Microeconomic Evidence from Developed and Developing Countries. Industrial and Corporate Change 22 (6), 1453-95.

Vivarelli, M., \& Audretsch, D. B. (1998). The Link between the Entry Decision and Postentry Performance: Evidence from Italy. Industrial and Corporate Change 7 (3), 485-500.

Wagner, J. (1994). The post-entry performance of new small firms in German manufacturing industries. The Journal of Industrial Economics, 42, 141-154.

Wennekers, S., \& Thurik, A. R. (1999). Linking Entrepreneurship and Economic Growth. Small Business Economics, 13 (1), 27-55. 
Table 1 - Variable used in the empirical analysis

\begin{tabular}{llc}
\hline Variable & Measure & Time \\
\hline Survival time & Elapsed years since 2000 to exit & \\
Innovator & Dummy equal to 1 if the young company is an innovator, 0 & $1998-$ \\
& otherwise & 2000 \\
Product & Dummy equal to 1 if the young company is a product innovator, & $1998-$ \\
Innovator & 0 otherwise & 2000 \\
Process & Dummy equal to 1 if the young company is a process innovator, & $1998-$ \\
Innovator & 0 otherwise & 2000 \\
Prod\&Proc & Dummy equal to 1 if the young company is both a product and & $1998-$ \\
& a process innovator, 0 otherwise & 2000 \\
Age & Logarithm of firms age & 2000 \\
Agesq & Square of Age & 2000 \\
Size & Logarithm of firm sales & 2000 \\
Sizesq & Square of Firm Size & 2000 \\
\hline
\end{tabular}

Table 2 - Descriptive statistics

\begin{tabular}{lrrrrr}
\hline Variable & Obs & Mean & Std.Dev. & Min & Max \\
\hline Survival time & 1090 & 5.4445 & 2.3310 & 0.0000 & 7 \\
Innovator & 1090 & 0.4927 & 0.5002 & 0.0000 & 1.0000 \\
Product Innovator & 1090 & 0.4202 & 0.4938 & 0.0000 & 1.0000 \\
Process Innovator & 1090 & 0.3073 & 0.4616 & 0.0000 & 1.0000 \\
Prod\&Proc & 1090 & 0.2349 & 0.4241 & 0.0000 & 1.0000 \\
Age & 1090 & 1.1077 & 0.5975 & 0.0000 & 1.7918 \\
Agesq & 1090 & 1.5837 & 1.1091 & 0.0000 & 3.2104 \\
Size & 1090 & 0.7904 & 0.3146 & 0.0000 & 1.3863 \\
Sizesq & 1090 & 0.7236 & 0.5321 & 0.0000 & 1.9218 \\
\hline
\end{tabular}


Table 3 - Correlation matrix

\begin{tabular}{|c|c|c|c|c|c|c|c|c|c|}
\hline & $\begin{array}{r}\text { Survival } \\
\text { time }\end{array}$ & Age & Agesq & Size & Sizesq & Innovator & $\begin{array}{l}\text { Product } \\
\text { Innovator }\end{array}$ & $\begin{array}{l}\text { Process } \\
\text { Innovator }\end{array}$ & Prod\&Proc \\
\hline Survival time & 1.000 & & & & & & & & \\
\hline Age & 0.066 & 1.000 & & & & & & & \\
\hline Agesq & 0.041 & 0.958 & 1.000 & & & & & & \\
\hline Size & 0.140 & 0.038 & 0.038 & 1.000 & & & & & \\
\hline Sizesq & 0.108 & 0.031 & 0.032 & 0.946 & 1.000 & & & & \\
\hline Innovator & 0.065 & 0.045 & 0.051 & 0.300 & 0.326 & 1.000 & & & \\
\hline Product Innovator & 0.026 & 0.050 & 0.057 & 0.290 & 0.323 & 0.864 & 1.000 & & \\
\hline Process Innovator & 0.121 & 0.012 & 0.020 & 0.288 & 0.311 & 0.676 & 0.464 & 1.000 & \\
\hline Prod\&Proc & 0.086 & 0.018 & 0.028 & 0.298 & 0.329 & 0.562 & 0.651 & 0.832 & 1.000 \\
\hline
\end{tabular}


Table 4 - Survival rates

\begin{tabular}{cccccc}
\hline Year & $\begin{array}{c}\text { Non- } \\
\text { innovators }\end{array}$ & Innovators & $\begin{array}{c}\text { Product } \\
\text { Innovators }\end{array}$ & $\begin{array}{c}\text { Process } \\
\text { Innovators }\end{array}$ & Prod\&Proc \\
\hline 0 & $100.0 \%$ & $100.0 \%$ & $100.0 \%$ & $100.0 \%$ & $100.0 \%$ \\
1 & $92.6 \%$ & $95.2 \%$ & $94.5 \%$ & $96.7 \%$ & $96.1 \%$ \\
2 & $87.7 \%$ & $90.7 \%$ & $90.0 \%$ & $94.3 \%$ & $94.1 \%$ \\
3 & $81.4 \%$ & $83.2 \%$ & $82.1 \%$ & $88.7 \%$ & $88.3 \%$ \\
4 & $76.0 \%$ & $79.1 \%$ & $78.0 \%$ & $83.9 \%$ & $83.2 \%$ \\
5 & $71.6 \%$ & $76.9 \%$ & $75.8 \%$ & $81.8 \%$ & $81.2 \%$ \\
6 & $62.4 \%$ & $70.2 \%$ & $68.1 \%$ & $74.3 \%$ & $71.9 \%$ \\
7 & $58.1 \%$ & $64.4 \%$ & $63.1 \%$ & $67.2 \%$ & $65.6 \%$ \\
\hline
\end{tabular}


Table 5 - Tests for equality of survivor functions

Innovators vs Non-Innovators

\begin{tabular}{lrr}
\hline Test & Chi-square & Pr $>$ Chi-Square \\
Log Rank & 2.80 & 0.0940 \\
\hline Product Innovators vs Non-innovators & & Pr $>$ Chi-Square \\
\hline Test & Chi-square & 0.4057 \\
Log Rank & 0.69 & \\
\hline Process Innovators vs Non-innovators & & Pr $>$ Chi-Square \\
\hline Test & Chi-square & 0.0251 \\
Log Rank & 5.02 & \\
\hline Prod\&Proc vs Non-innovators & & Pr $>$ Chi-Square \\
\hline Test & & 0.1471 \\
Log Rank & Chi-square & \\
\hline Age & 2.10 & Pr $>$ Chi-Square \\
\hline Test & & 0.5893 \\
Cox & & Pr $>$ Chi-Square \\
& Chi-square & 0.0000 \\
\hline Size & 0.29 & \\
\hline Test & & \\
Cox & Chi-square & \\
\hline
\end{tabular}


Table 6 - Maximum Likelihood Parameter Estimates

\begin{tabular}{|c|c|c|c|c|c|}
\hline & $(1)$ & (2) & (3) & (4) & $(5)$ \\
\hline Innovator & $\begin{array}{c}0.1224 \\
(0.0948)\end{array}$ & & & & \\
\hline Product Innovator & & $\begin{array}{c}0.0614 \\
(0.0969)\end{array}$ & & $\begin{array}{l}-0.0278 \\
(0.1040)\end{array}$ & \\
\hline Process Innovator & & & $\begin{array}{c}0.2350^{* *} \\
(0.1008)\end{array}$ & $\begin{array}{c}0.2458 * * \\
(0.1085)\end{array}$ & \\
\hline Prod\&Proc & & & & & $\begin{array}{l}0.2000^{*} \\
(0.1117)\end{array}$ \\
\hline Age & $\begin{array}{c}0.5775^{* *} \\
(0.2585)\end{array}$ & $\begin{array}{c}0.5740^{* *} \\
(0.2586)\end{array}$ & $\begin{array}{c}0.6023 * * \\
(0.2575)\end{array}$ & $\begin{array}{c}0.6019 * * \\
(0.2575)\end{array}$ & $\begin{array}{c}0.5987 * * \\
(0.2581)\end{array}$ \\
\hline Agesq & $\begin{array}{c}-0.3048^{* *} \\
(0.1392)\end{array}$ & $\begin{array}{c}-0.3025^{* *} \\
(0.1392)\end{array}$ & $\begin{array}{c}-0.3155^{* *} \\
(0.1386)\end{array}$ & $\begin{array}{c}-0.3148^{* *} \\
(0.1386)\end{array}$ & $\begin{array}{c}-0.3146^{* *} \\
(0.1389)\end{array}$ \\
\hline Size & $\begin{array}{l}1.1789 * * \\
(0.4198)\end{array}$ & $\begin{array}{l}1.1677^{* *} \\
(0.4202)\end{array}$ & $\begin{array}{l}1.1979 * * \\
(0.4174)\end{array}$ & $\begin{array}{c}1.1931 * * \\
(0.4176)\end{array}$ & $\begin{array}{l}1.1974 * * \\
(0.4185)\end{array}$ \\
\hline Sizesq & $\begin{array}{c}-0.4089 \\
(0.2550)\end{array}$ & $\begin{array}{c}-0.3846 \\
(0.2552)\end{array}$ & $\begin{array}{l}-0.4507^{*} \\
(0.2536)\end{array}$ & $\begin{array}{c}-0.4435^{*} \\
(0.2549)\end{array}$ & $\begin{array}{c}-0.4379 * \\
(0.2548)\end{array}$ \\
\hline Industry dummies & Yes & Yes & Yes & Yes & Yes \\
\hline Constant & $\begin{array}{c}6.5753 \\
(410.8985) \\
\end{array}$ & $\begin{array}{c}6.6944 \\
(407.4701)\end{array}$ & $\begin{array}{c}6.6790 \\
(709.1406) \\
\end{array}$ & $\begin{array}{c}6.6666 \\
(709.0942)\end{array}$ & $\begin{array}{c}6.6815 \\
(419.8411) \\
\end{array}$ \\
\hline$N$ & 1023 & 1023 & 1023 & 1023 & 1023 \\
\hline Log-likelihood & -886.2360 & -886.8714 & -884.3360 & -884.3004 & -885.4610 \\
\hline
\end{tabular}


Figure 1 Comparison of survival function between Innovators and Non-Innovators

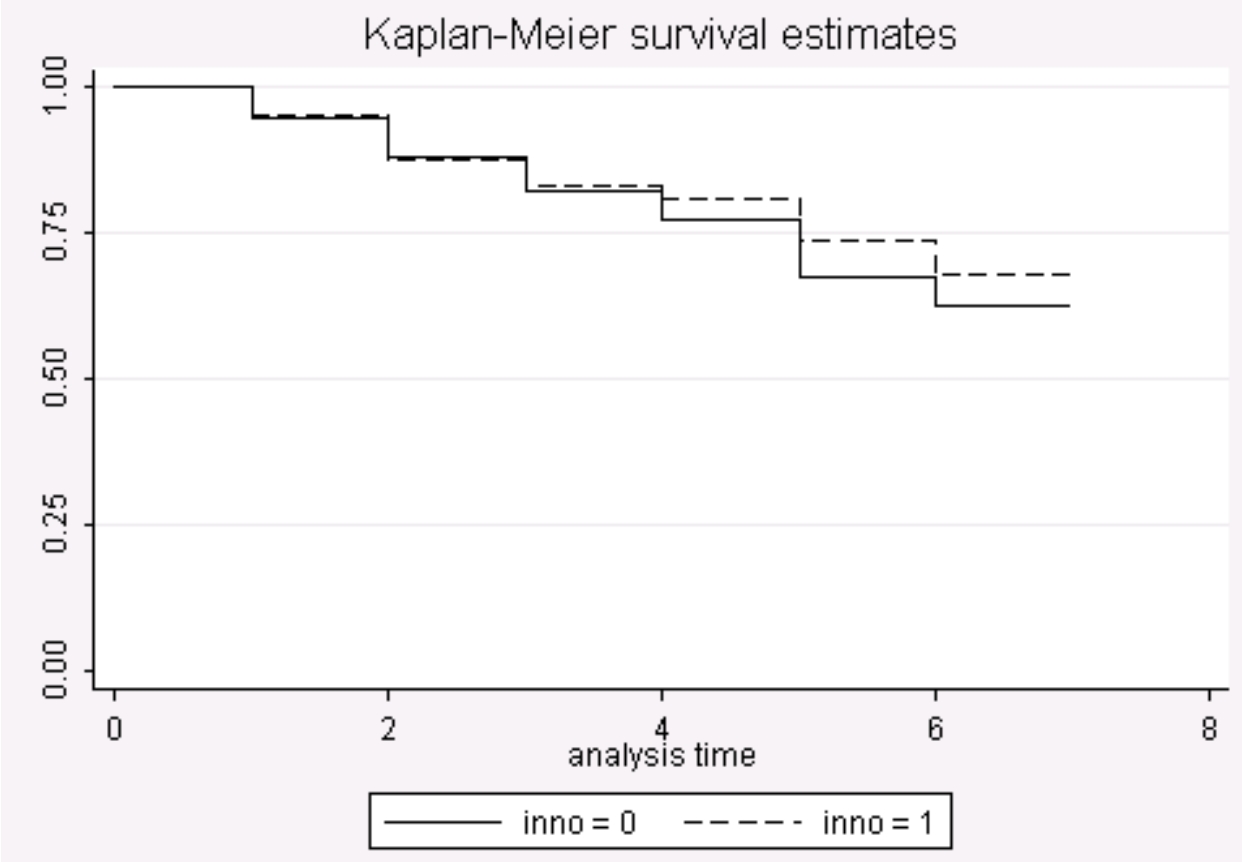

Figure 2 Comparison of survival function between Process Innovators and NonInnovators

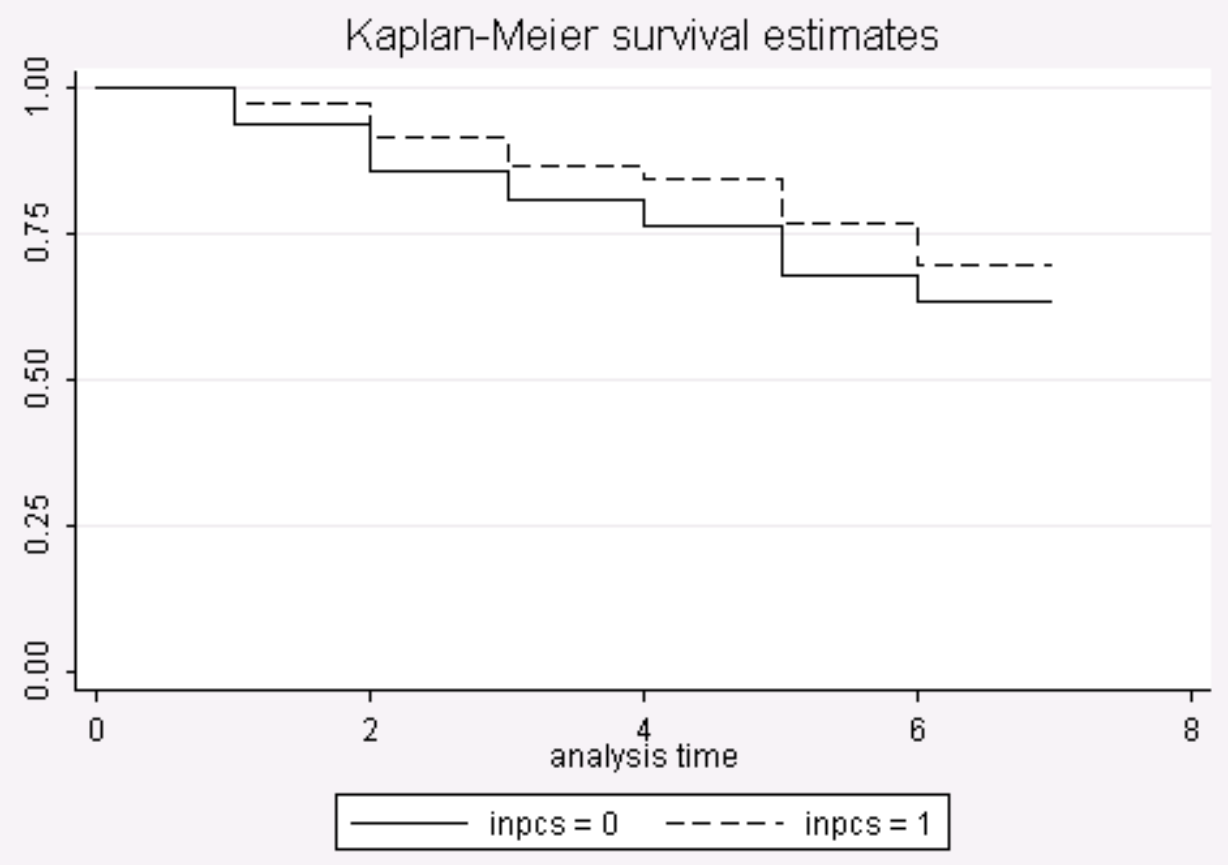


Figure 3 Comparison of survival function between Product Innovators and NonInnovators

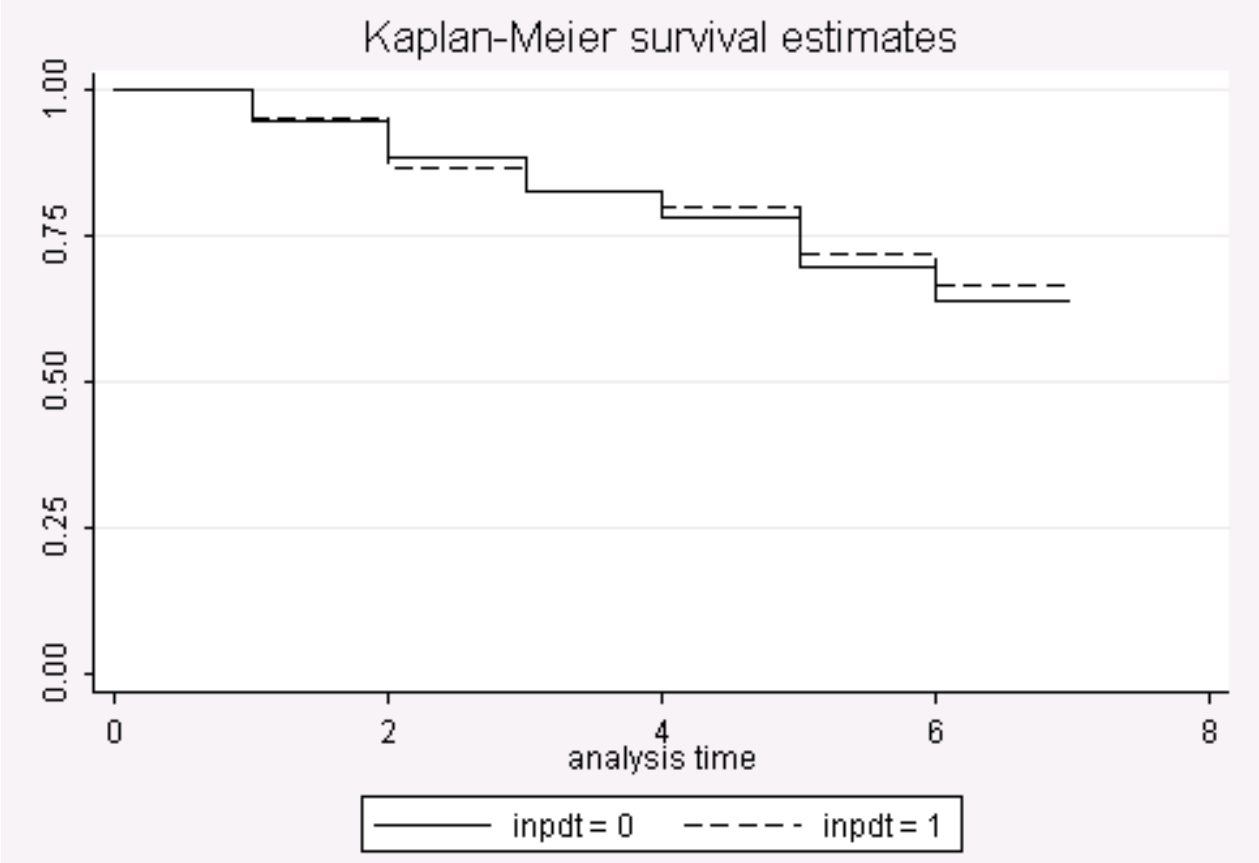

Figure 4 Comparison of survival function between Prod\&Proc and Non-Innovators

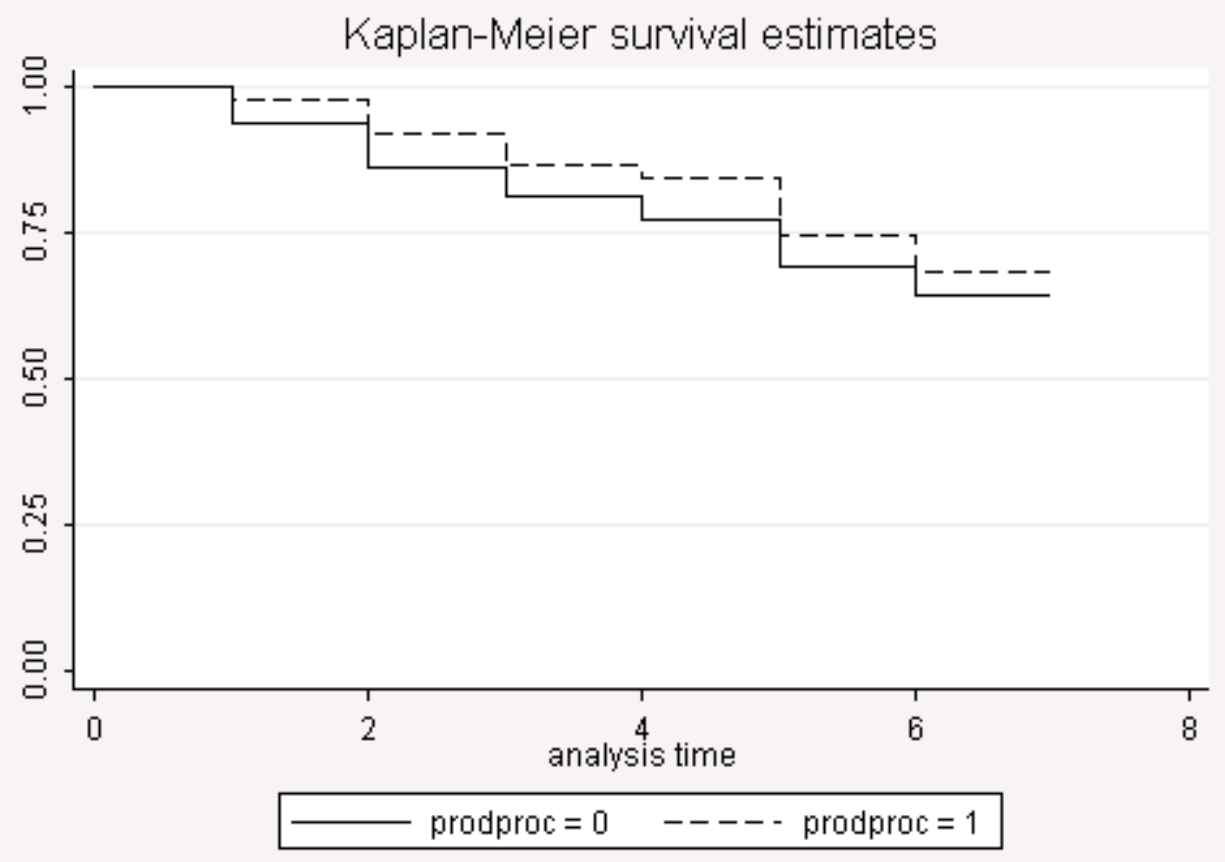


Figure 5 Comparison of survival function: Product Innovators, Process Innovators, Prod\&Proc and Non-Innovators

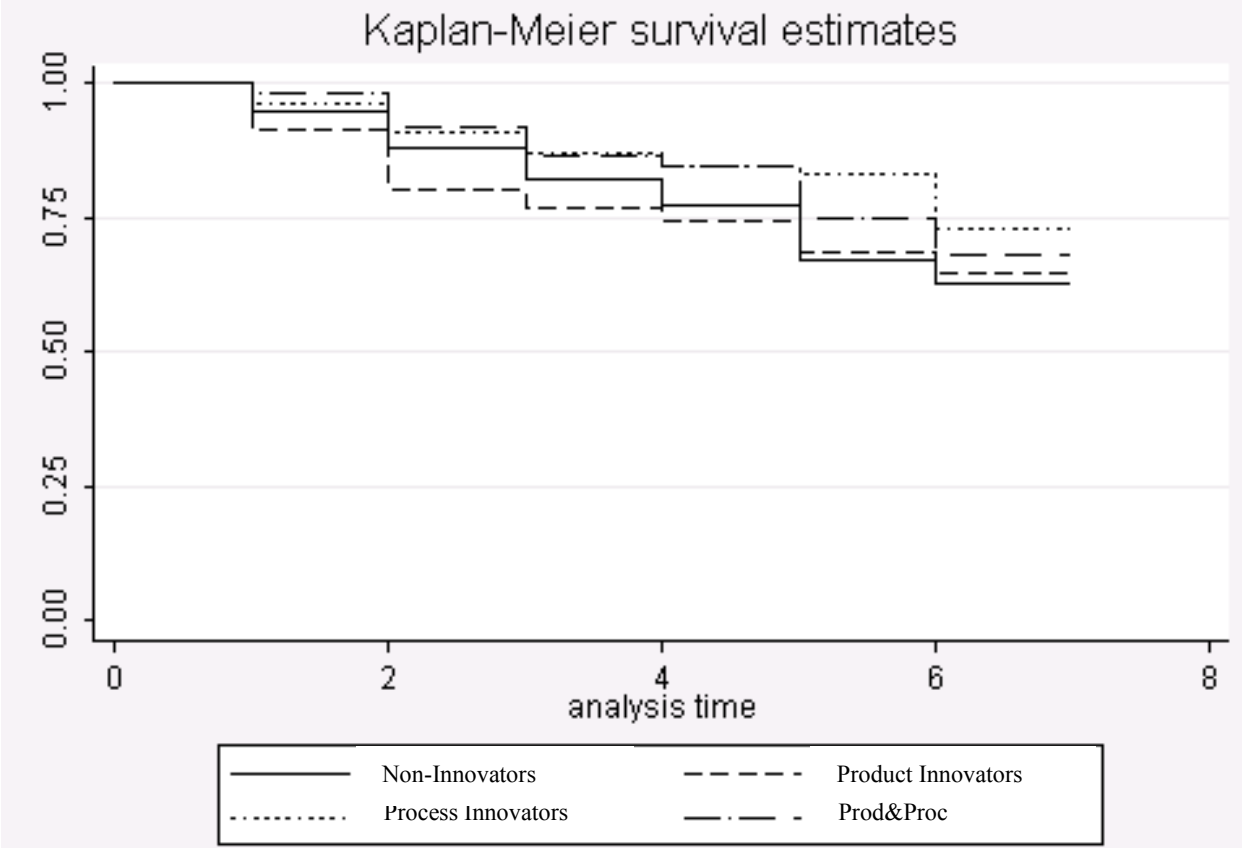

